\title{
Ájurvéda az elhízás kezelésében
}

\author{
Korossy Anna TDK-hallgató - Blázovics Anna dr.
}

Semmelweis Egyetem, Gyógyszerésztudományi Kar, Farmakognóziai Intézet, Budapest

\begin{abstract}
Az életmód változásával és a gyorséttermi láncok elterjedésével egyre nagyobb problémát jelent az elhízás az egész világon. Indiában a férfiak $31 \%$-a, a nők $29 \%$-a túlsúlyos, és az elhízás az utóbbi 11 évben növekvő tendenciát mutat. Az elhízás növeli számos betegség kialakulásának esélyét, mint például a szív- és érrendszeri betegségek, refluxbetegség, gastrointestinalis tumorok és alvási apnoe. Mútétek során a szövődményekkel még nem járó elhízás is súlyos komplikációkat okozhat. Az Ájurvédában a betegségek kialakulásáért a 3 dosha - vata, pitta, kapha - egyensúlyának felborulása a felelős. A 3 dosha aránya egyénenként változik, és meghatározza az egyéni testalkatot. Egy indiai kutatócsoport kimutatta, hogy az ájurvédikus testtípus-besorolás kapcsolatba hozható a gyulladásos és oxidatívstresszfaktorok génjeivel, a DNS-metilációval és a cardiovascularis betegségek kialakulásának esélyeivel. Orv. Hetil., 2016, 157(34), 1349-1352.
\end{abstract}

Kulcsszavak: Ájurvéda, elhízás, dyslipidaemia, testtípus, DNS-metiláció

\section{Ayurveda for the treatment of obesity}

Obesity is an increasing problem all over the world as the lifestyle changes and fast food chains gain popularity. In India, $31 \%$ of men and $29 \%$ of women are overweight, which is a growing trend over the last 11 years. Obesity increases the risk of many diseases such as cardiovascular diseases, reflux disease, gastrointestinal tumors, and sleep apnea. Obesity without complications can also cause serious complications during surgery. In Ayurveda the formation of diseases depends on the balance of the three doshas - vata, pitta, kapha. The rate of three doshas varies depending on the body constitution of the indvidual. Studies of an Indian research group have shown that Ayurvedic body type classification may be associated with genes of inflammation and oxidative stress factors, the rate of DNA methylation and development of cardiovascular diseases.

Keywords: Ayurveda, obesity, dyslipidemia, body type, DNA methylation

Korossy, A., Blázovics, A. [Ayurveda for the treatment of obesity]. Orv. Hetil., 2016, 157(34), 1349-1352.

(Beérkezett: 2016. május 8.; elfogadva: 2016. június 1.)

\begin{abstract}
Rövidítések
$\mathrm{AMP}=$ adenozin-monofoszfát; $\mathrm{AP}-1=$ activator protein- 1 ; $\mathrm{BMI}=($ body mass index $)$ testtömegindex; $\mathrm{CoA}=$ koenzim-A; COX-2 = ciklooxigenáz-2; DNS = dezoxiribonukleinsav; $\mathrm{FPG}=$ (fasting plasma glucose concentration $)$ éhomi plazmaglükóz-koncentráció; HDL = (high density lipoprotein) magas sűrűségű lipoprotein; HLA = humán leukocyta-antigén; HOMA-IR = homeostatic model assessment of insulin resistance; hs-CRP $=($ high sensitive $\mathrm{C}$-reactive protein $)$ magas érzékenységű C-reaktív protein; IL-1 $\beta=$ interleukin- $1-\beta$; IL-6 = interleukin-6; iNOS = indukálható nitrogén-monoxid-szintáz; $\mathrm{LDL}=$ (low density lipoprotein $)$ alacsony sưrúségű lipoprotein; LPS = lipopoliszacharid; $\mathrm{mRNS}=$ messenger ribonukleinsav; $\mathrm{NO}=$ nitrogén-monoxid; $\mathrm{PGE}_{2}=$ prosztaglandin $\mathrm{E}_{2}$; $\mathrm{SNP}=$ single nucleotide polymorphism; $\mathrm{TG}=$ triglicerid; TNF- $\alpha=$ tumornekrózis-faktor $-\alpha$; WHO = World Health Organization
\end{abstract}

\section{India és az elhízás}

Az életmód változásával és a különböző gyorséttermi láncok térhódításának köszönhetően az egész világon egyre nagyobb jelentőséggel bír az obesitas leküzdése. A WHO 2015-ös statisztikája szerint Indiában a férfiak $31 \%$-a, a nók $29 \%$-a túlsúlyos, s ez növekvő tendenciát mutat, 2005 óta a túlsúlyos férfiak száma 9\%-kal, a túlsúlyos nők száma 8\%-kal nőtt.

Indiában a cukorfogyasztás tradicionális. Vallási fesztiválokon, szociális összejöveteleken édességek fogyasztásával ünnepelnek. Brazília után India a második legnagyobb cukornádtermelő a világon, a tradicionális süteményeik, édességeik 65-98\%-ban tartalmaznak nádcukrot. Egyre növekvő számban jelennek meg az úgynevezett dhabas boltok (kis bolt) az országutak, főutak 
mentén, ahol cukortartalmú italokat, turmixokat lehet vásárolni. Gulati és Misra tanulmánya szerint Indiában 2013-ban a diabetes mellitusban szenvedők száma 65,1 millió volt, így Kína után a második helyen áll a világon [1].

Egy Indiában végzett kutatás szerint a 20 és 30 év közötti fiatalok $(\mathrm{n}=1117)$ körében a praehypertensio (a szisztolés vérnyomás 120-139 Hgmm között és/vagy a diasztolés nyomás 80-89 Hgmm között) 45,2\%-os, míg a hypertensio (a szisztolés nyomás $140 \mathrm{Hgmm}$ fölött és a diasztolés nyomás $90 \mathrm{Hgmm}$ fölött) 3\%-os előfordulással jelent meg. A vérnyomás mérésén kívül a kutatásban részt vevőket többek között a családi állapotukról, vallási nézetükről, iskolai végzettségükről, étkezési és sportolási szokásaikról is kérdezték. Személyes adatszolgáltatás alapján a túlzott sófogyasztók 68\%-a, a dohányzók 77\%-a, a napi szinten cukros üdítőt fogyasztók $46 \%$-a a praehypertensiós csoportba került, a BMI-érték alapján a túlsúlyosak $83 \%$-a praehypertensiós [2].

\section{Az ájurvédikus táplálkozás}

Az Ájurvéda az élelmiszereket és gyógynövényeket 3 fó tulajdonság szerint „gúnába” sorolja. A „szattvikus” ételek energiát szolgáltatnak a testnek, a „tamasz” és „radzsasz" kevésbé erôsíti a szervezetet, utóbbiakból ezért mérsékelten szabad csak fogyasztani, azonban mindhárom gúna megléte szükségszerü az egészséges táplálkozáshoz. A szattvikus ételek közé tartoznak a könnyen emészthető ételek, a gabonafélék, a búza, kukorica, zab, rizs, a gyümölcsök, a lisztes és az olajos magvak, mint például a gesztenye, a mogyoró és a kókusz. A nehéz, zsíros ételek és az alkohol a tamaszikus csoportba sorolhatók, míg a radikálisan sós, savanyú és édes ételek a radzsaszikus gúnához tartoznak. Az Ájurvéda azt állítja, hogy a gyógynövények íze tájékoztatást ad annak tulajdonságairól. Az Ájurvédában 6-féle ízt különböztetnek meg, ezek: a keserü, a sós, a savanyú, az édes, a fanyar és a csípős. A füszeres ízű gyógynövények hőtermelő és serkentő hatásúak, míg a keserü gyógynövények hưtő hatásúak, lázcsökkentők. India tradicionális készítménye a „ghi” (vajféleség). Készítésekor a vajat melegítik, felforralják, a felső habréteget leszedve a maradék fehérje- és zsírrétegből több órán át tartó melegítéssel alakul ki a ghi [3]. Patkányokkal végzett kísérletek igazolták, hogy a ghivel adott konjugált linolsav jobban csökkenti a szérumban az összkoleszterinszintet, a szérumtrigliceridszintet és növeli a HDL-koleszterin-szintet, mint a szójababolajjal kiegészített diéta, valamint növeli a májban lévő kataláz és szuperoxid-dizmutáz enzimek aktivitását [4].

A Hatha Jóga Pradipika a beavatás előtt álló jógiknak étrendi tanácsot is ad. Fontos azonban kiemelni, hogy ez az étrend meglehetősen limitált tápanyagbevitelt biztosít. Az előírás szerint kerülni kell a keserü, a savanyú, a sós, a mustármagos ételek fogyasztását, valamint a halat, a húst és a „részegíto”” italokat. Amíg az illető nem érte el a jógában, meditációban és a légzőgyakorlatokban a megfelelő szintet, addig a limitált tápanyag-bevitelü táplálkozást nem szabad elkezdenie [5].

\section{Az elhízás kórélettani hatásai}

Az obesitas növeli számos betegség kialakulásának a kockázatát, mint például a szív- és érrendszeri betegségek, refluxbetegség, gastrointestinalis tumorok, alvási apnoe és egyéb más kór megjelenését. Mütétek során a szövődményekkel még nem járó obesitas is súlyos gondot okozhat. Az obesitas következményeként kialakuló zsírmáj az újabb kutatások szerint már szisztémás gyulladásnak tekinthető, ugyanis fokozódik a TNF- $\alpha$, COX-2 és az iNOS szintéziséért felelős mRNS-ek szintje [6].

Dél-indiai túlsúlyos személyek vizsgálata során kiderült, hogy ók magas összkoleszterin-, LDL-koleszterinés TNF- $\alpha$-szinttel rendelkeztek a nem túlsúlyos kontrollcsoportokhoz képest. A vizsgáltak BMI-értéke 23,0-24,9 $\mathrm{kg} / \mathrm{m}^{2}$ között mozgott. Fóleg a visceralis zsírszövetekben figyelhető meg krónikus gyulladás, amely felelőssé tehető számos kóros folyamat, többek között az inzulinrezisztencia kialakulásáért [7].

Vidal kutatása szerint az IL-6, TNF- $\alpha$ és a hs-CRP szignifikánsan korrelál az FPG-inzulin- és a HOMA-IRszinttel diabetesben, metabolikus szindrómában és inzulinrezisztenciában szenvedő betegek esetében. Az obesitas, illetve a krónikus gyulladás fennállása igen veszélyes lehet mütétek során. A súlyos szövődmények kialakulása is gyakoribb a magas BMI-jü betegeknél [8].

\section{A testtípus és a genom kapcsolata}

Az Ájurvédában a betegségek kialakulásáért a 3 dosha vata, pitta, kapha - egyensúlyának felborulása a felelős. Ezek a szanszkrit szavak nagyon nehezen fordíthatók le nyugati kifejezésekre: alapelv(?), nedv(?). Az öt alapelem - az éter, a levegő, a tûz, a víz és a föld - doshaként van jelen az emberi szervezetben, és ennek a három doshának az aránya egyénenként változik. Ez az arány határozza meg a prakritit, vagyis a testalkatot. A vatát úgy lehet jellemezni, mint azt a testi levegőt, energiát, amely a biológiai mozgást irányítja. A pittát a testi hőenergiának fordíthatjuk, amely irányítja az emésztést, az étel felszívódását, a táplálkozást. A kapha biológiai vízként jelenik meg egyes ösi forrásokban, amely kitölti a testben lévő üregeket és a testben lévő folyadékterekben jelenik meg. A túl sok kapha megzavarja az anyagcserét, túlzott anabolizmust eredményez, a kaphadomináns alkatú emberek hízásra hajlamosak [9]. Egy indiai kutatócsoport vizsgálatai kimutatták, hogy az ájurvédikus testtípus-besorolás kapcsolatba hozható: SNP-k (single nucleotide polymorphism) megjelenésével, mint a HLA-DRB17, CYP2C198, EGLN19 gyulladásos és oxidatívstressz-faktorok génjei, DNS-metilációval, cardiovascularis betegségek kialakulásának esélyeivel. Az Ájurvéda testtípusbesorolásának módszere és tudományos háttere egyre 
sürgetőbb kérdés lehet az orvostudományban [10]. A testtípusok között különbségek jelennek meg a lipidprofilban és a hematológiai paraméterekben. Prakritibesorolás után végzett vérvizsgálatok kimutatták, hogy a kaphacsoport tagjaiban alacsonyabb HDL-, magasabb LDL-koleszterin- és TG-szint mérhető, szemben a vataés pittacsoportokkal. Hosszabb protombinidő jellemezte a vatacsoportot, összehasonlítva a másik két csoport eredményeivel. A „kaphaférfiak” vizsgálata során a magas LDL-koleszterin-szint, csökkent protrombinidő és a fibrinolitikus gének alacsony expressziója volt jellemző, amely magas cardiovascularis kockázatot jelent. A prakriti alkalmas lehet betegségek predikciójának vizsgálatára, azonban a kutatás során a női nemi ciklus folyamatos változása miatt egy testtípuson belül is jelentős heterogenitás jelenik meg a nők körében [11].

\section{Az elhízás kezelése az Ájurvédában}

India köztudottan a jóga hazájának tekinthető, illetve az Ájurvéda is ajánlja a mindennapos jógagyakorlást. A jógának számos jótékony hatása ismert, ezért az utóbbi években megnövekedett a jógával kapcsolatos kutatások száma is. Ornish, a kaliforniai egyetem orvosprofesszora klinikai vizsgálatokkal bizonyította és publikálta eredményeit 1990-ben a The Lancet orvosi folyóiratban, amelyben leírja, hogy a súlyos koszorúér-betegség progressziója megállítható, egyes esetekben a beteg állapota javítható gyógyszerek és sebészeti beavatkozás nélkül is. $\mathrm{Az}$ úgynevezett Ornish-program 4 alapeleme a zsírszegény laktoovovegetáriánus (a növényi élelmiszereken kívül tojást és tejet is fogyasztó) diéta, fokozatosan felépített mozgásprogram, amely aerob tréningből és mindennapi jógagyakorlásból - stresszkezelés jógával, meditációval, légzőgyakorlatokkal - és heti rendszerességû támogató csoportokban való részvételből áll. A bypassmütétekre váró betegek csoportjában már 2 hét alatt csökkent az anginás események száma. Az Ornish-kezelés után egy évvel pedig 82\%-kal szignifikánsan kevesebb érszúkület volt látható a felvételek szerint, és az anginák száma 91\%-kal csökkent. Frattaroli, Weidner, MerrittWorden és mtsai kimutatták, hogy az obesitassal kapcsolt lehet a telomer rövidülése, amely egy meghatározott életmód-változtatással javítható. A telomerek a kromoszómák végén találhatók és a sejtosztódások során egyre rövidebbek lesznek. Ha a telomerek elérnek egy bizonyos méretet, a sejt nem osztódik tovább, beindul az öregedés [12, 13].

A kórosan megnövekedett BMI-hez társuló dyslipidaemia magas trigliceridszintet, alacsonyabb HDL- és megnövekedett LDL-szintet jelenthet, amelyek növelik az atherosclerosis kialakulásának kockázatát. A dyslipidaemia megelőzésére, illetve kezelésére 4 csoportba sorolták a gyógynövényeket, amelyekból az adott beteg testtípus-besorolása után kiválasztják a legmegfelelőbbet. A gyógynövények az indiai klasszikus irodalomból származnak: a Charaka Sambita, Sushruta Sambita,
Ashtanga sangraha, Ashtanga Hrudaya könyvekböl. A gyógynövényeket keserú íz, meleg potencia, könnyú és száraz tulajdonságú gyógynövényi csoportokba sorolják [14].

A dyslipidaemia kezelésére alkalmas lehet a Magyarországon is megjelenő Cyperus rotundus L. (rizspalka), amelynek gyökeréből készített kivonatából először izolálták a fulgidsavat és pinelsavat. RAW246,7 makrofágokon végzett kísérletek alapján kimutatták, hogy a fulgidsav gátolja az LPS-indukált TNF- $\alpha$-, IL-6- és $\mathrm{PGE}_{2}$-expressziót, valamint a NO-képződést az AP-1 transzkripciós faktor inaktivációján keresztül [15].

Hasonlóan a rizspalkához, az indiai törpebogáncs, a Saussurea lappa Decne gyökerének alkoholos kivonata is inaktiválja az AP-1 transzkripciós faktort, amely gátlóhatást egér- és patkánykísérletekben is bebizonyították. Kosztunolid- (germakránvázas, 10 tagú monociklikus szeszkviterpén lakton) tartalma gátolja az IL-1 $\beta$-mRNS expresszióját, hozzájárulva az antiinflammatorikus hatáshoz. Túlsúlyos nyulakon végzett kísérletekben bebizonyosodott, hogy az indiai törpebogáncs gyökerének vizes kivonata per os adagolva hypolipidaemiás hatású, szignifikánsan csökkent a szérum triglicerid- és koleszterinszintje [16].

Emésztési nehézségek, keringési elégtelenség, ízületi problémák, sokféle bőrbetegség esetén javasolják a Curcuma longa L. gyógynövényt. Számos biológiailag aktív komponense ismert: kurkumin, demetoxikurkumin és biszdemetoxikurkumin. A Curcuma longa L. alkoholos kivonata a zsírsavszintetáz, acetil-CoA-karboxiláz, lipoproteinlipáz expressziójának csökkentésével gátolja a lipogenezist, serkenti a lipolízist és a béta-oxidációt többek között a hormonszenzitív lipáz expressziójának növelésével és AMP-aktivált proteinkináz foszforilációjával [17].

Az elhízás kezelése mellett a Derris indica Bennet szárából izolált két új piranoflavonoid, a derrisin A és B alkalmas lehet előrehaladott glikációs végtermékek (advanced glycation end-product - AGE) gátlására, ami fontos tényező a vesebetegségek prognózisában és a cukorbetegség szövődményeinek kialakulásában [18].

Az Ájurvéda-kezelések közé tartozik a Virechana (terápiás megtisztulás) egyike, a Panchakarma (biopurifikációs módszer) olyan anyagcsere-betegségekben, mint a kóros elhízás és/vagy cukorbetegség. Fruktózindukált metabolikus szindrómában szenvedő albínó patkányokat vetettek alá Virechana-terápiának. E terápia során hashajtást végeznek többek között Sennae radix (szennagyökér), Pruni fructus (szilvatermés), Lini semen (lenmag), Taraxaci radix (gyermekláncfügyökér), tehéntej és só felhasználásával. A terápiának köszönhetően csökkent a patkányok székletének zsírtartalma, szérumtriglicerid-szintje és az éhgyomri vércukorszint. A szabadzsírsav-szint csökkent a szívben, a májban és a vesében, ami közvetett módon növelte az inzulinreceptorok inzulin iránti érzékenységét [9, 19]. 
Napjainkban egyre szélesebb körben alkalmazzák fogyás céljára azokat a nagy rosttartalmú étrend-kiegészítőket, amelyek bő folyadékkal bevéve megduzzadnak és teltségérzetet okoznak, csökkentve ezzel az éhségérzetet. Az Ájurvédában is használatos a teltségérzetet kiváltó útifümaghéj (Plantaginis ovatae semen et testa), amely egy placebokontrollos kísérletben igazolta, hogy használatával csökkent a napi kalória- és zsírbevitel [20].

\section{Következtetések}

Az ájurvédikus táplálkozás a doshák egyensúlyban tartására törekszik, amely figyelembe veszi az úgynevezett „gúnákat”, a szattvikus, a tamasz és a radzsasz típusú élelmiszerek fogyasztását. Az elhízás elleni küzdelemben a több évezredes megfigyelések jól korrelálnak a mai nyugati orvoslás ajánlásaival. Gyógynövénykészítményeik hasznosnak bizonyulnak a metabolikus eltérések mérséklésére. Magyarországon is egyre nagyobb érdeklődés tapasztalható a különböző étrendek iránt, így igen időszerü az ájurvédikus táplálkozás további kutatása, vizsgálata.

Anyagi támogatás: A közlemény megírása anyagi támogatásban nem részesült.

Szerzői munkamegosztás: K. A.: Ájurvéda-kutatás. B. A.: A kézirat szerkesztése. A cikk végleges változatát mindkét szerző elolvasta és jóváhagyta.

Érdekeltségek: A szerzőknek nincsenek érdekeltségeik.

\section{Irodalom}

[1] Gulati, S., Misra, A.: Sugar intake, obesity, and diabetes in India Nutrients, 2014, 6(12), 5955-5974.

[2] Kini, S., Kamath, G. V., Kulkarni, M. M., et al.: Pre-hypertension among young adults (20-30 years) in coastal villages of Udupi District in Southern India: An alarming scenario. PLoS ONE, 2016, 11(4), e0154538.

[3] Frawley, D., Lad, V.: Medical herbs - an Ayurvedic guide. [Gyógynövények - Ayurvédikus útmutató.] Édesvíz Kiadó, Budapest, 2015. [Hungarian]

[4] Chinnadurai, K., Kanwal, K. H., Tyagi, K. A., et al.: High conjugated linoleic acid enriched ghee (clarified butter) increases the antioxidant and antiatherogenic potency in female Wistar rats. Lipids Health Dis., 2013, 12, 121.

[5] Sinh, P.: Hatha Yoga Pradipika. Munshiram Manoharlal Publisher, New Delhi, 1997.

[6] Hegediis, V., Geró, D., Mibály, Z., et al.: Alimentary induced fatty liver and adjuvant therapy with effective natural bioactive molecules. [Alimentáris eredetű kísérletes zsírmáj és adjuváns kezelése természetes eredetű bioaktív hatóanyagokkal.] Orv. Hetil., 201 l, 152(26), 1035-1042. [Hungarian]
[7] Premanath, M., Basavanagowdappa, H., Mahesh, M., et al.: Chronic sub-clinical inflammation in the abdominal adipose tissue - Evaluation of inflammatory cytokines and their link with insulin resistance in metabolically obese South Indians: A crosssectional observational study. Indian J. Endocrinol. Metab., 2016, 20(1), 84-91.

[8] Marques-Vidal, P., Bastardot, F, von Känel, R., et al.: Association between circulating cytokine levels, diabetes and insulin resistance in a population-based sample (CoLaus study). Clin. Endocrinol., 2013, 78(2), 232-241.

[9] Lad, V.: Ayurveda. [Ayurveda.] Édesvíz Kiadó Kft., Budapest, 2015. [Hungarian]

[10] Govindaraj, P., Nizamuddin, S., Sharath, A., et al.: Genomewide analysis correlates. Ayurveda Prakriti. Sci. Rep., 2015, 5, 15786. DOI: $10.1038 / \operatorname{srep} 15786$.

[11] Prasher, B., Negi, S., Aggarwal, S., et al.: Whole genome expression and biochemical correlates of extreme constitutional types defined in Ayurveda. J. Transl. Med., 2008, 6, 48.

[12] Ornish, D., Brown S. E., Scherwitz, L. W., et al.: Can lifestyle changes reverse coronary atherosclerosis? The Lifestyle Heart Trial. Lancet, 1990, 336(8708), 129-133.

[13] Falus, A., Marton, I., Borbényi, E., et al.: 2009 Nobel Prize in Medicine and an interesting message: telomerase activity is associated with lifestyle. [A 2009. évi orvosi Nobel-díj és egy meglepő üzenete: az életmód befolyásolja a telomerázaktivitást.] Orv. Hetil., 2010, 151(24), 965-970. [Hungarian]

[14] Kumari, H., Pushpan, R., Nishteswar, K.: Medohara and Lekhaniya dravyas (anti-obesity and hypolipidemic drugs) in Ayurvedic classics: A critical review. Ayu, 2013, 34(1), 11-16.

[15] Shin, S. J., Hong, Y., Lee, H. H., et al.: Fulgidic acid isolated from the rhizomes of Cyperus rotundus suppresses LPS-induced iNOS, COX-2, TNF- $\alpha$, and IL- 6 expression by AP-1 inactivation in RAW264.7 macrophages. Biol. Pharm. Bull., 2015, 38(7), 1081-1086.

[16] Zahara, K., Tabassum, S., Sabir, S., et al.: A review of therapeutic potential of Saussurea lappa - An endangered plant from Himalaya. Asian Pac. J. Trop. Med., 2014, 7(Suppl. 1), S60-S69.

[17] Kim, J. H., Kim, O. K., Yoon, H. G., et al.: Anti-obesity effect of extract from fermented Curcuma longa L. through regulation of adipogenesis and lipolysis pathway in high-fat diet-induced obese rats. Food Nutr. Res., 2016, 60, 30428.

[18] Anusiri, P., Choodej, S., Chumriang, P., et al.: Inhibitory effects of flavonoids from stem bark of Derris indica on the formation of advanced glycation end products. J. Ethnopharmacol., 2014, 158 (Part A), 437-441

[19] Chaturvedi, A., Rao, P. N., Kumar, M. A., et al.: Effect and mechanism of Virechana Karma (Therapeutic Purgation) over fructose-induced metabolic syndrome: An experimental study. J. Evid. Based Complementary Altern. Med., 2016, 21(3), 194201.

[20] Turnbull, W. H., Thomas, H. G.: The effect of a Plantago ovata seed containing preparation on appetite variables, nutrient and energy intake. Int. J. Obes. Relat. Metab. Disord., 1995, 19(5), 338-342.

(Korossy Anna,

Budapest, Üllői út 26., 1085

e-mail: blazovics.anna@pharma.semmelweis-univ.hu korossy.panna@gmail.com) 